Nahanga Verter*

Libor Grega **
JEL Classification : F14, Q23, Q27

Professional paper

https://doi.org/10.32910/ep.70.5.4

\title{
EXPORT PERFORMANCE AND COMPETITIVENESS IN WOOD PRODUCTS IN THE CZECH REPUBLIC AND AUSTRIA
}

This article assesses the development of wood exports in the Czech Republic (Czechia) and Austria in recent years. Some approaches, such as revealed comparative advantage ( $R C A)$, relative trade balance index $(R T B)$, and diversification ratios are used to assess the export performance and competitiveness indicators in these countries. The RCA result reveals that both Czechia and Austria have been competitive in the global wood markets, just as the countries have witnessed positive in RTB within the period under study. Market diversification results indicate that both countries concentrated in few markets (mainly within the EU single market) for exports of wood products. Also, the competitiveness based on the product structure shows that both countries, notably Austria wood product groups have been diversified and mostly processed before exports. In summary, both countries have performed impressively within the period under study even though the time series for the research was short. Nevertheless, there is a need for market export diversification beyond the EU's single market.

Keywords: export, competitiveness, diversification, market, RCA, RTB

${ }^{*}$ N. Verter, Ph.D., Assistant Professor, Department of Regional and Business Economics, Faculty of Regional Development and International Studies, Mendel University in Brno, Czech Republic (e-mail: nahanga.verter@mendelu.cz).

${ }^{*}$ L. Grega, Ph.D., Full Professor, Department of Regional and Business Economics, Faculty of Regional Development and International Studies, Mendel University in Brno, Czech Republic (e-mail: libor.grega@ mendelu.cz).

The paper was received on August 10th, 2018. It was accepted for publication on November 3rd, 2018. 


\section{INTRODUCTION}

Productivity leads to competitiveness (Porter, 1990; WEF, 2018). Global competitiveness is a measure of an economy's advantage or disadvantage in selling its products or commodities in the world markets (WEF, 2018). Thus, trade competitiveness is the ability of an economy to produce products that meet the test of global competition (Krugman, 1994). Trade competitiveness and performance are always regarded as synonymous, and competitiveness of an economy is often identified with its export performance (Sujová \& Hlaváčková, 2015; Priede \& Pereira, 2015; Zdráhal \& Bečvářová, 2018). Similarly, countries are globally competitive when exported more in value-added products than imports. There are many products traded across the globe depending on the individual country's competitive or comparative advantage. This article focuses on the export trade in forestry (wood) resources in recent years.

The socio-economic contribution of wood products measured by the jobs and wealth created in an economy (Nambiar, 2015; FAO, 2014a; FAO, 2014b; FAO, 2016; UNECE/FAO, 2018; FAO, 2018). Forest exports improve trade balances, contributing to the value added (the lead to GDP growth) in countries, such as Czechia (FAO, 2014a; FAO, 2014b).

It is not farfetched to argue that countries dispose of above-average stock of wood products and utilise it for economic development (FAO, 2014a; Nambiar, 2015). Recent studies have attempted to assess the performance of the wood industry in some countries. For instance, Gonuguntla (2007) uses the RCA index to analyse the performance and competitiveness of New Zealand's wood products. The findings show that the country's comparative advantage rose in high valueadded and declined in low value-added wood products. Arguably, New Zealand has specialised more in wood processing for exports and local consumption.

Noor et al. (2008) use the RCA to analyse the performance of Malaysia in exporting the wood products to the global market. The results reveal that the country has a comparative advantage in wood and forest products (except furniture) to the European market.

Han et al. (2009) assess the status and competitiveness of the Chinese wooden furniture industry using Balassa's RCA Index. Their results reveal that China has witnessed a transition from a comparative disadvantage into a high comparative advantage over the period in the wood industry (especially bedroom wooden furniture). Nevertheless, they argue that the country still falls behind traditionally strong competitors, regarding quality and unit price of the furniture.

Similarly, de Carvalho et al. (2009) use RCA to evaluate the competitiveness of Brazilian wood pulp in the global market and observed that Brazil ranked 
among the top competitive nations in the global market of wood pulp products. Their finding further reveals that Brazil and some countries such as Canada, Chile, Finland, the USA, Sweden and Indonesia have a comparative advantage in wood pulp exports for the period between 2000 and 2006.

Recent studies have attempted to analyse the performance of forest sector or wood industry in Czech Republic (Kupčák \& Šmída, 2015; Bojnec \& Fertő, 2014; Paluš et al., 2015; Sujová \& Hlaváčková, 2015; Sujová et al., 2017) and Austria (Dieter and Englert (2007; Bojnec \& Ferto, 2011; Granabetter, 2016; UNECE/ FAO, 2017).

Dieter and Englert (2007) analyses the competitiveness of 21 countries (i.e. Germany, Austria, USA, Poland, Finland, Russia) in wood products in the global timber markets, using Balassa RCA approaches. The study was carried out based on the level of value added (from raw, semi-processed to processed) wood products. The results show that highest Balassa RCA index values are shown by Russia for raw wood (10.4), by Finland for semi-processed wood products (11.3) and by Poland for processed wood products (4.7). Germany revealed to have had RCA somewhat higher than 1 for processed wood products. They argue that exporting raw wood is not an indication of competitiveness in the wood industry. Exporting countries that substantially trade with high value-added wood products are more likely to remain competitive in the global market.

Paluš et al. (2015) assess trade performance and competitiveness in the wood processing industry in Slovak with reference to the Visegrad countries between 2003 and 2012. Using Export/Import Ratio, Trade Specialization Index, Standard Grubel-Lloyd Index (GL Index), and RCA approaches, their results show that Slovakia has a comparative advantage in most of the wood product groups, notably coniferous and non-coniferous sawnwood, paper and paperboard and wood-based panels. Their findings further indicate and increasing intra-industry specialisation with the level of value- added to products.

Also, given that forest covered about $34.5 \%$ and $47 \%$ (of land area) in Czechia and Austria respectively in 2015 (World Bank, 2018), and wood products accounted for about $2 \%$ and 5\% share in total national exports in Czechia and Austria, respectively in 2016 (ITC, 2018), the relevance of the wood sector in these countries cannot be overemphasized.

This study attempts to contribute to the existing literature, and throw light on the development of trade in wood products in recent years. Thus, this article aimed at analyzing the trade performance, structure (product groups), competitiveness and specialisation in the wood products in Czechia and Austria. 


\section{MATERIALS AND METHODS}

In this article, secondary data are mainly used to assess the performance of wood trade in Czechia and Austria. Specifically, annual statistical data were obtained from the International Trade Centre (ITC) to analyse the development of wood products in these countries for the period between 2012 and 2016.

Also, the methods for the study are substantially adopted from the ITC. The ITC developed trade performance within the framework of the Harmonized System (HS; see Table 1), aimed at assessing and monitoring the multifaceted dimensions (structure) of export competitiveness by industry and by country. The wood product groups (at 4 digits level) are divided from raw, semi-processed to processed products.

Table 1.

\section{HS- STANDARD INTERNATIONAL TRADE CLASSIFICATION (SITC) REVISION 3 WOOD PRODUCT GROUPS}

\begin{tabular}{|l|l|}
\hline Industry & Industry- wood and articles of wood \\
\hline 4400 & All industries in sector 44 \\
\hline 4401 & Fuel wood; wood in chips or particles; sawdust and wood waste and scrap \\
\hline 4402 & Wood charcoal (including shell or nut charcoal) \\
\hline 4403 & Wood in the rough \\
\hline 4404 & Hoop wood; split poles; piles, pickets, stakes; chipwood \\
\hline 4405 & Wood wool; wood flour \\
\hline 4406 & Railway or tramway sleepers (cross-ties) of wood \\
\hline 4407 & Wood sawn/chipped lengthwise, sliced/peeled \\
\hline 4408 & Veneer sheets and sheets for plywood and other wood sawn lengthwise \\
\hline 4409 & Wood continuously shaped along any edges \\
\hline 4410 & Particle board and similar board of wood or other ligneous materials \\
\hline 4411 & Fibreboard of wood or other ligneous materials \\
\hline 4412 & Plywood, veneered panels and similar laminated wood \\
\hline 4413 & Densified wood, in blocks, plates, strips or profile shapes \\
\hline 4414 & Wooden frames for paintings, photographs, mirrors or similar objects \\
\hline 4415 & Packaging materials of wood \\
\hline 4416 & Casks, barrels, vats, tubs, etc. of wood \\
\hline 4417 & Tools, tool and broom bodies and handles, shoe lasts of wood \\
\hline 4418 & Builders' joinery and carpentry of wood \\
\hline 4419 & Tableware and kitchenware of wood \\
\hline 4420 & Wood marquetry and inlaid wood; caskets and cases or cutlery of wood \\
\hline 4421 & Articles of wood, nes \\
\hline
\end{tabular}

Source: ITC 
Table 2 presents the rationale and the calculation of each indicator in the TPI. The indicators are divided into three sections: general profile indicators; the composite index (CI) indicators; and the Decomposition of changes (change-related indicators) in the world market. All indicators are calculated at the product level. ITC uses original data in the calculation is at the 6-digit level of the HS nomenclature (1996 edition).

Table 2.

\section{WOOD TRADE PERFORMANCE INDEX}

\begin{tabular}{|c|c|c|}
\hline General description & Code & Indicator's description \\
\hline \multirow{7}{*}{ General Profile } & $\mathrm{N}$ & Number of exporting countries for the ranking in the sector \\
\hline & G1 & Value of exports (in billions US\$) \\
\hline & $\mathrm{G} 2$ & Export growth in value $(\%)$ \\
\hline & G3 & Share in national exports $(\%)$ \\
\hline & G4 & Share in national imports $(\%)$ \\
\hline & G5 & Relative trade balance (\%)- RTB \\
\hline & G6 & Relative unit value (world average $=1$ ) \\
\hline \multirow{5}{*}{$\begin{array}{l}\text { Position for Current } \\
\text { Index (the composite } \\
\text { index }(\mathrm{CI}) \text { ) }\end{array}$} & $\mathrm{P} 1$ & Net exports (in billions US\$) \\
\hline & $\mathrm{P} 2$ & Per capita exports (thousand US\$/inhabitant) \\
\hline & $\mathrm{P} 3$ & Share in the world market $(\%)$ \\
\hline & $\mathrm{P} 4$ & Product diversification (Number of equivalent products) \\
\hline & P5 & Market diversification (Number of equivalent markets) \\
\hline \multirow{5}{*}{$\begin{array}{l}\text { Decomposition of } \\
\text { changes in world market } \\
\text { share (last } 5 \text { years) }\end{array}$} & $\mathrm{C} 1$ & Relative change in world market share (\%) \\
\hline & C1a & Competitiveness effect $(\%)$ \\
\hline & $\mathrm{C} 1 \mathrm{~b}$ & Initial geographic specialization (\%) \\
\hline & C1c & Initial product specialization $(\%)$ \\
\hline & C1d & Adaptation effect (\%) \\
\hline Indicators included & A & Absolute change of world market share (\% points) \\
\hline
\end{tabular}

Source: ITC

Relative trade balance (RTB) shows the ratio between the trade balance and the total trade of a given economy. The ratio indicates if a nation is a net exporter (where national production outweighs consumption) and vice versa. The model is mathematically written as follows:

$$
R T B_{d s}^{t}=100 x \frac{X_{d s}^{t}-M_{d s}^{t}}{X_{d s}^{t}+M_{d s}^{t}}
$$


Where $t$ is the current year, $d$ is the nation under study, $s$ is the selected sector, $X$ denotes exports, and $M$ denotes imports. The range of values takes between $-100 \%$ and $+100 \%$, with positive values signifying that the nation is a net exporter, whereas negative values mean that the nation is a net importer. Interestingly, RTB reduces bias against large industries, which tend to have either high deficits or surpluses.

It is also essential to assess how far an economy diversifies its products and markets for export. Product diversification is a good indicator of production structures and industry's development level. In this study, it intends the measure the identical number of wood product groups exported in a given period. The model is mathematically written as follows:

$$
N D P X_{d s}^{t}=1 / H I P_{d s}^{t}
$$

Where HIP is the Herfindahl Index, calculated as follows:

$$
H I P_{d s}^{t}=\sum_{p=1}^{n p_{s}}\left(\frac{X_{d p, s}^{t}}{X_{d s}^{t}}\right)^{2}
$$

Where $X_{d p, s}^{t}$ is the export of product $p$ by country $d$ for a given year $t ; X_{d s}^{t}$ is country $d$ exports of all products belonging to the sector $s ; \frac{X_{d p}^{t}}{X_{d s}^{t}}$ is the share of product $p$ in total exports of country $d$ in sector $s$. The index takes values between 0 and $+\infty$. The larger the index value, the greater the diversification of exports, and thus, the better the ranking and vice versa.

Similarly, market diversification shows a country's degree of market concentration (of wood export markets in this study): diversifying partner nation reduces its reliance on a few numbers of markets, and thus the vulnerability to shocks within destination countries. The model is mathematically written as follows:

$$
N D M X_{d s}^{t}=1 / H I M_{d s}^{t}
$$

Where HIP is the Herfindahl Index, calculated as follows:

$$
H I M_{d s}^{t}=\sum_{m=1}^{n m_{s}}\left(\frac{X_{d m, s}^{t}}{X_{d s}^{t}}\right)^{2}
$$


Where $X_{d m, s}^{t}$ is the export of all (wood) products belonging to sector $s$ by country $d$ to market $m$, for a given year $t ; X_{d s}^{t}$ is country $d$ exports of all products belonging to sector $s ; \frac{X_{d m, s}^{t}}{X_{d s}^{t}}$ is the share of product $p$ in total exports of country $d$ in sector $s$. Diversification limits the reliance on a small number of products and thus reduces a nation's vulnerability to industry-specific external shocks (ITC, 2018).

In international trade, it is necessary to assess if a nation has an advantage over the other in some products or sectors. The concept of 'revealed' comparative advantage (RCA) was coined by Liesner (1958); and later developed by Balassa $(1965 ; 1979)$. Thus, known as 'Balassa index', which is now widely used empirically to identify a nation's most robust and weakest export sectors worldwide (Bojnec and Fertő, 2014). Similarly, the model has been used in the forestry and wood sectors in recent years (Han et al., 2009; Bojnec and Fertő, 2012; Sujová and Hlaváčková, 2015; Sujová et al., 2017). The index tries to identify product groups where the targeted nation has a distinct advantage in the world market. Interestingly, RCA brings out comparative advantages/disadvantages in global markets and sheds more light on the factors causing those movements. The RCA index is mathematically presented as followers:

$$
R C A_{d, i}=\frac{X_{d, i}}{X_{d}} / \frac{X_{w, i}}{X_{W}}
$$

Where; $d$ is the nation under study, $w$ indicates the set of all exporting nations, $i$ signifies a specific industry and $X$ are the exports. If it takes a value of less than 1 , this implies that the country is not specialised in exporting the product (the share of that product in the country under review's exports is less than the corresponding world share). Similarly, if the index exceeds 1 , this implies that the country is specialised in exporting the item.

It is important to reiterate that Czechia and Austria are selected for this research because both countries have long-standing political and economic relations in addition to sharing borders and being the EU member states. Also, the topic is chosen because the authors believe that their study would bring additional knowledge to the wood sector in Czechia and Austria. Also, given that the importance of wood products has been recognized worldwide (Arnold, 2002; UNECE, 2017ba, 2017b; UNECE/FAO, 2017), the authors assume that this research is relevant. Arguably, the findings in this current study may reveal the development of the wood sector and areas that should be given adequate attention for better performance and competitiveness in the world market. 


\section{RESULTS AND DISCUSSION}

The exports of forest products in Central and Eastern European (CEE) countries grew tremendously between 2000 and 2011, albeit at a lower base. Poland, Czechia, Lithuania, and Hungary were among the nations in the region that recorded the highest growth within the period (FAO, 2014a). In 2017, Austria accounted for about $3.7 \%$ and ranked 6 , while Czechia accounted for about $1.6 \%$, and ranked 19th position in global wood (SITC 44) exports. On the other hand, Austria accounted for $2.2 \%$ and ranked 10 , while Czechia accounted for $0.7 \%$, and ranked 27 in the global wood imports (ITC, 2018).

\section{Table 3 .}

TRADE PERFORMANCE HS (US\$, MILLIONS, \%, INDICES) IN CZECHIA, 2012-2016

\begin{tabular}{|c|c|c|c|c|c|c|c|c|c|c|c|}
\hline Industry-SITC 2012 & 4400 & 4407 & 4403 & 4410 & 4418 & 4415 & 4401 & 4412 & 4421 & 4408 & 4409 \\
\hline Exports (US\$, millions) & 1,964 & 433 & 400 & 304 & 225 & 200 & 86 & 86 & 59 & 57 & 49 \\
\hline Balance (US\$, millions) & 976 & 246 & 200 & 174 & 121 & 153 & 51 & 28 & 27 & 15 & 12 \\
\hline RTB & 33.1 & 39.7 & 33.3 & 40.1 & 36.7 & 62.2 & 41.6 & 19.3 & 29.7 & 15.5 & 14.4 \\
\hline Exports (\% of total national exports) & 1.26 & 0.28 & 0.26 & 0.19 & 0.14 & 0.13 & 0.05 & 0.05 & 0.04 & 0.04 & 0.03 \\
\hline Imports (\% of total national imports) & 0.71 & 0.13 & 0.14 & 0.09 & 0.07 & 0.03 & 0.03 & 0.04 & 0.02 & 0.03 & 0.03 \\
\hline Exports (\% of world exports) & 1.67 & 1.38 & 3.03 & 4.20 & 1.62 & 6.87 & 1.31 & 0.60 & 1.15 & 2.08 & 1.03 \\
\hline Imports (\% of world imports) & 0.79 & 0.56 & 1.15 & 1.82 & 0.84 & 1.72 & 0.43 & 0.43 & 0.55 & 1.39 & 0.75 \\
\hline Share of top 3 export markets (\%) & 68.6 & 54.6 & 97.3 & 62.8 & 67.6 & 87.2 & 91.2 & 58.9 & 45.5 & 51.1 & 56.2 \\
\hline Share of top 3 exported products (\%) & 46.1 & 99.2 & 95.1 & 99.7 & 89.0 & 100 & 85.1 & 91.0 & 85.1 & 91.4 & 100 \\
\hline Balassa Index/RCA Index & 2.0 & 1.6 & 3.7 & 4.8 & 2.0 & 6.5 & 1.3 & 0.6 & 1.3 & 4.0 & 1.0 \\
\hline Industry- SITC 2013 & 4400 & 4403 & 4407 & 4410 & 4418 & 4415 & 4401 & 4412 & 4421 & 4408 & 4409 \\
\hline Exports (US\$, millions) & 2,166 & 512 & 441 & 322 & 235 & 223 & 107 & 89 & 63 & 59 & 48 \\
\hline Balance (US\$, millions) & 1,143 & 279 & 264 & 187 & 136 & 166 & 62 & 27 & 34 & 22 & 15 \\
\hline RTB & 35.9 & 37.4 & 42.7 & 41.1 & 41.0 & 59.3 & 41.2 & 17.7 & 36.0 & 23.4 & 18.4 \\
\hline Exports (\% of total national exports) & 1.34 & 0.32 & 0.27 & 0.20 & 0.15 & 0.14 & 0.07 & 0.05 & 0.04 & 0.04 & 0.03 \\
\hline Imports (\% of total national imports) & 0.72 & 0.16 & 0.12 & 0.09 & 0.07 & 0.04 & 0.03 & 0.04 & 0.02 & 0.03 & 0.02 \\
\hline Exports (\% of world exports) & 1.66 & 3.14 & 1.24 & 4.04 & 1.47 & 7.11 & 1.41 & 0.59 & 1.18 & 2.14 & 1.00 \\
\hline Imports (\% of world imports) & 0.75 & 1.15 & 0.48 & 1.69 & 0.72 & 2.01 & 0.48 & 0.45 & 0.48 & 1.22 & 0.67 \\
\hline Share of top 3 export markets (\%) & 69.9 & 97.9 & 55.0 & 67.5 & 65.2 & 87.7 & 93.6 & 60.7 & 46.0 & 52.7 & 59.0 \\
\hline Share of top 3 exported products (\%) & 48.8 & 95.9 & 99.2 & 99.9 & 86.8 & 100 & 81.8 & 89.8 & 100 & 100 & 100 \\
\hline Balassa Index/RCA Index & 2.0 & 3.6 & 1.4 & 5.0 & 1.9 & 7.0 & 1.8 & 0.6 & 1.3 & 4.0 & 1.0 \\
\hline Industry- SITC 2014 & 4400 & 4403 & 4407 & 4410 & 4415 & 4418 & 4412 & 4401 & 4421 & 4408 & 4409 \\
\hline Exports (US\$, millions) & 2,251 & 500 & 472 & 346 & 244 & 231 & 101 & 99 & 69 & 68 & 55 \\
\hline
\end{tabular}


N. VERTER, L. GREGA: Export performance and competitiveness in wood products in the Czech Republic and Austria EKONOMSKI PREGLED, 70 (5) 743-764 (2019)

Table 3. Continued

\begin{tabular}{|c|c|c|c|c|c|c|c|c|c|c|c|}
\hline Balance (US\$, millions) & 1,167 & 276 & 266 & 198 & 177 & 134 & 31 & 57 & 31 & 31 & 20 \\
\hline RTB & 35.0 & 38.1 & 39.2 & 39.9 & 56.7 & 41.0 & 17.9 & 40.5 & 28.7 & 29.8 & 22.9 \\
\hline Exports ( $\%$ of total national exports) & 1.29 & 0.29 & 0.27 & 0.20 & 0.14 & 0.13 & 0.06 & 0.06 & 0.04 & 0.04 & 0.03 \\
\hline Imports ( $\%$ of total national imports) & 0.71 & 0.15 & 0.13 & 0.1 & 0.04 & 0.06 & 0.05 & 0.03 & 0.02 & 0.02 & 0.02 \\
\hline Exports (\% of world exports) & 1.63 & 2.94 & 1.24 & 4.39 & 7.18 & 1.40 & 0.61 & 1.22 & 1.19 & 2.41 & 1.05 \\
\hline Imports (\% of world imports) & 0.74 & 0.97 & 0.51 & 1.84 & 2.21 & 0.69 & 0.48 & 0.41 & 0.58 & 1.15 & 0.67 \\
\hline Share of top 3 export markets ( $\%)$ & 70.2 & 98.0 & 51.9 & 74.8 & 86.3 & 63.8 & 58.3 & 93.2 & 41.3 & 50.2 & 56.9 \\
\hline Share of top 3 exported products $(\%)$ & 49.2 & 97.9 & 99.2 & 100 & 86.0 & 90.7 & 83.3 & 100 & 100 & 100 & 87.4 \\
\hline Balassa Index/RCA Index & 1.8 & 3.2 & 1.4 & 5.0 & .0 & 1.4 & 0.7 & 1.5 & 1.3 & 4.0 & 1.0 \\
\hline Industry- SITC 2015 & 4400 & 4403 & 4407 & 4410 & 4418 & 4415 & 4412 & 4401 & 4421 & 4408 & 4409 \\
\hline Exports (US\$, millions) & 1,891 & 406 & 357 & 272 & 211 & 210 & 103 & 96 & 64 & 63 & 49 \\
\hline Balance (US\$, millions) & 946 & 226 & 171 & 139 & 127 & 145 & 38 & 58 & 36 & 23 & 23 \\
\hline RTB & 33.4 & 38.6 & 31.5 & 34.6 & 43.2 & 52.7 & 22.5 & 43.3 & 39.0 & 22.9 & 31.2 \\
\hline Exports ( $\%$ of total national exports) & 1.20 & 0.26 & 0.23 & 0.17 & 0.13 & 0.13 & 0.07 & 0.06 & 0.04 & 0.04 & 0.03 \\
\hline Imports (\% of total national imports) & 0.67 & 0.13 & 0.13 & 0.09 & 0.06 & 0.05 & 0.05 & 0.03 & 0.02 & 0.03 & 0.02 \\
\hline Exports (\% of world exports) & 1.53 & 3.08 & 1.08 & 3.96 & 1.39 & 6.93 & 0.68 & 1.26 & 1.13 & 2.31 & 1.05 \\
\hline Imports (\% of world imports) & 0.73 & 1.04 & 0.51 & 1.91 & 0.65 & 2.31 & 0.46 & 0.42 & 0.45 & 1.27 & 0.55 \\
\hline Share of top 3 export markets $(\%)$ & 70.7 & 98.3 & 55.6 & 77.2 & 62.2 & 85.2 & 57.5 & 91.7 & 45.0 & 44.4 & 58.7 \\
\hline Share of top 3 exported products (\%) & 46.6 & 98.1 & 99.3 & 100 & 82.3 & 100 & 86.6 & 100 & 100 & 100 & 90.8 \\
\hline Balassa Index/RCA Index & 1.6 & 3.3 & 1.2 & 4.3 & 1.4 & 6.5 & 0.8 & 1.2 & 1.3 & 2.0 & 1.0 \\
\hline Industry- SITC 2016 & 4400 & 4403 & 4407 & 4410 & 4418 & 4415 & 4412 & 4401 & 4408 & 4421 & 4409 \\
\hline Exports (US\$, millions) & 1,995 & 471 & 344 & 281 & 217 & 212 & 108 & 106 & 69 & 69 & 49 \\
\hline Balance (US\$, millions) & 1,042 & 320 & 159 & 146 & 120 & 144 & 42 & 65 & 26 & 39 & 20 \\
\hline RTB & 35.4 & 51.6 & 30.2 & 35.1 & 38.2 & 51.4 & 24.5 & 44.4 & 23.7 & 39.3 & 26.3 \\
\hline Exports (\% of total national exports) & 1.24 & 0.29 & 0.21 & 0.17 & 0.13 & 0.13 & 0.07 & 0.07 & 0.04 & 0.04 & 0.03 \\
\hline Imports (\% of total national imports) & 0.68 & 0.11 & 0.130 & 0.10 & 0.07 & 0.05 & 0.05 & 0.03 & 0.03 & 0.02 & 0.02 \\
\hline Exports (\% of world exports) & 1.58 & 3.54 & 0.99 & 3.75 & 1.41 & 6.95 & 0.71 & 1.36 & 2.43 & 1.21 & 1.07 \\
\hline Imports (\% of world imports) & 0.74 & 0.92 & 0.51 & 1.81 & 0.74 & 24.00 & 0.48 & 0.46 & 1.35 & 0.49 & 0.63 \\
\hline Share of top 3 export markets $(\%)$ & 72.5 & 57.4 & 80.1 & 60.0 & 83.3 & 58.1 & 91.4 & 47.8 & 43.8 & 57.9 & 65.0 \\
\hline Share of top 3 exported products (\%) & 46.6 & 98.0 & 99.5 & 100.0 & 79.6 & 100 & 83.7 & 88.4 & 100 & 100 & 100 \\
\hline Balassa Index/RCA Index & 1.6 & 3.6 & 1.0 & 3.4 & 1.3 & 6.5 & 0.8 & 1.4 & 2.0 & 1.0 & 1.0 \\
\hline
\end{tabular}

Source: Authors' analysis based on ITC, 2018. Note: See table 1 for the names of the product groups (SITC); *RTB index $=$ relative trade balance

Trade performance and competitiveness in wood products and product groups in Czechia and Austria for the period 2012-2016 is presented in Table 3 and Table 4 respectively. In other words, this section shows the results of the dynamics of the overall wood export products, product groups (based on SITC level 4), and RCA in the above countries. Table 3 shows that Czechia's wood export (SITC 44) fluctuated over the years, slowly increased from $\$ 1.96$ billion in 2012 to $\$ 2.25$ billion in 2014, then declined to $\$ 1.89$ billion in 2015, before rising to $\$ 1.995$ billion in 2016 . 
Table 4.

TRADE PERFORMANCE HS (US\$, MILLIONS, \%, INDEX) IN AUSTRIA, 2012-2016

\begin{tabular}{|c|c|c|c|c|c|c|c|c|c|c|c|}
\hline Industry- SITC 2012 & 4400 & 4407 & 4418 & 4410 & 4411 & 4412 & 4401 & 4409 & 4403 & 4421 & 4408 \\
\hline Exports (US\$, millions) & 4,849 & 1,438 & 1,381 & 737 & 419 & 264 & 174 & 126 & 93 & 66 & 62 \\
\hline Balance (US\$, millions) & 1,903 & 786 & 1,043 & 574 & 318 & 119 & -78 & 36 & -652 & -94 & -40 \\
\hline RTB & 24.4 & 37.6 & 60.6 & 63.7 & 60.9 & 29.1 & -18.4 & 16.8 & -77.8 & -41.6 & -24.5 \\
\hline Exports (\% of total national exports) & 2.91 & 0.86 & 0.83 & 0.44 & 0.25 & 0.16 & 0.10 & 0.08 & 0.06 & 0.04 & 0.04 \\
\hline Imports (\% of total national imports) & 1.65 & 0.37 & 0.19 & 0.09 & 0.06 & 0.08 & 0.14 & 0.05 & 0.42 & 0.09 & 0.06 \\
\hline Exports (\% of world exports) & 4.13 & 4.57 & 9.97 & 10.18 & 4.32 & 1.84 & 2.64 & 2.63 & 0.7 & 1.29 & 2.26 \\
\hline Imports (\% of world imports) & 2.37 & 1.95 & 2.72 & 2.29 & 1.07 & 1.08 & 3.08 & 1.84 & 4.3 & 2.78 & 3.38 \\
\hline Share of top 3 export markets (\%) & 61.3 & 68.0 & 66.4 & 55.9 & 49.7 & 68.5 & 94.6 & 73.5 & 90.7 & 66.3 & 52.6 \\
\hline Share of top 3 exported products (\%) & 59.0 & 98.0 & 87.0 & 100 & 94.1 & 99.1 & 96.3 & 100 & 95.9 & 100 & 100 \\
\hline Balassa Index/RCA Index & 4.6 & 5.1 & 11.9 & 11.0 & 5.0 & 2.0 & 2.5 & 2.7 & 0.9 & 1.3 & 4.0 \\
\hline Industry- SITC 2013 & 4400 & 4407 & 4418 & 4410 & 4411 & 4412 & 4401 & 4409 & 4403 & 4408 & 4415 \\
\hline Exports (US\$, millions) & 5,102 & 1,510 & 1,455 & 737 & 465 & 280 & 208 & 130 & 101 & 63 & 57 \\
\hline Balance (US\$, millions) & 1,899 & 843 & 1,031 & 581 & 344 & 166 & -143 & 41 & -743 & -33 & -52 \\
\hline RTB & 22.9 & 38.7 & 54.9 & 65.0 & 58.7 & 42.2 & -25.6 & 18.9 & -78.6 & -20.8 & -31.2 \\
\hline Exports (\% of total national exports) & 2.91 & 0.86 & 0.83 & 0.42 & 0.27 & 0.16 & 0.12 & 0.07 & 0.06 & 0.04 & 0.03 \\
\hline Imports (\% of total national imports) & 1.75 & 0.36 & 0.23 & 0.09 & 0.07 & 0.06 & 0.19 & 0.05 & 0.46 & 0.05 & 0.06 \\
\hline Exports (\% of world exports) & 3.91 & 4.25 & 9.1 & 9.27 & 4.68 & 1.85 & 2.75 & 2.72 & 0.62 & 2.29 & 1.82 \\
\hline Imports (\% of world imports) & 2.36 & 1.8 & 3.12 & 1.97 & 1.24 & 0.83 & 3.76 & 1.8 & 4.15 & 3.2 & 3.84 \\
\hline Share of top 3 export markets (\%) & 59.9 & 65.6 & 66.2 & 54.5 & 46.7 & 69.4 & 95.0 & 74.9 & 91.5 & 50.3 & 64.0 \\
\hline Share of top 3 exported products (\%) & 58.8 & 98.2 & 87.4 & 99.9 & 95.1 & 98.9 & 96.0 & 100 & 95.4 & 100 & 100 \\
\hline Balassa Index/RCA Index & 4.3 & 4.5 & 10.4 & 10.5 & 5.4 & 2.0 & 3.0 & 2.3 & 0.7 & 4.0 & 1.5 \\
\hline Industry- SITC 2014 & 4400 & 4407 & 4418 & 4410 & 4411 & 4412 & 4401 & 4409 & 4403 & 4421 & 4408 \\
\hline Exports (US\$, millions) & 5,031 & 1,493 & 1,423 & 738 & 448 & 293 & 198 & 132 & 93 & 61 & 60 \\
\hline Balance (US\$, millions) & 1,962 & 848 & 1,042 & 590 & 303 & 173 & -127 & 33 & -673 & -90 & -39 \\
\hline RTB & 24.2 & 39.7 & 57.8 & 66.5 & 51.1 & 41.7 & -24.2 & 14.4 & -78.4 & -42.4 & -24.5 \\
\hline Exports (\% of total national exports) & 2.82 & 0.84 & 0.80 & 0.41 & 0.25 & 0.16 & 0.11 & 0.07 & 0.05 & 0.03 & 0.03 \\
\hline Imports (\% of total national imports) & 1.69 & 0.35 & 0.21 & 0.08 & 0.08 & 0.07 & 0.18 & 0.05 & 0.42 & 0.08 & 0.05 \\
\hline Exports (\% of world exports) & 3.64 & 3.93 & 8.62 & 9.36 & 4.32 & 1.77 & 2.44 & 2.54 & 0.54 & 1.06 & 2.12 \\
\hline Imports (\% of world imports) & 2.1 & 1.59 & 2.73 & 1.84 & 1.44 & 0.82 & 3.21 & 1.94 & 3.32 & 2.31 & 3.08 \\
\hline Share of top 3 export markets (\%) & 61.1 & 65.8 & 67.3 & 54.6 & 51.6 & 67.5 & 95.7 & 73.0 & 87.2 & 64.7 & 51.5 \\
\hline Share of top 3 exported products (\%) & 58.9 & 97.9 & 86.8 & 100 & 96.9 & 98.5 & 95.9 & 100 & 95.1 & 100 & 100 \\
\hline Balassa Index/RCA Index & 3.9 & 4.2 & 8.9 & 10.3 & 5.0 & 1.8 & 2.8 & 2.3 & 0.6 & 1.0 & 3.0 \\
\hline Industry- SITC 2015 & 4400 & 4407 & 4418 & 4410 & 4411 & 4412 & 4401 & 4409 & 4403 & 4421 & 4415 \\
\hline Exports (US\$, millions) & 4,351 & 1,299 & 1,236 & 635 & 386 & 215 & 169 & 132 & 86 & 54 & 54 \\
\hline Balance (US\$, millions) & 1,763 & 734 & 934 & 513 & 258 & 101 & -65 & 489 & -571 & -67 & -44 \\
\hline RTB & 25.4 & 39.4 & 60.8 & 67.7 & 50.2 & 30.9 & -16.2 & 22.8 & -76.9 & -38.0 & -29.2 \\
\hline
\end{tabular}


Table 4. Continued

\begin{tabular}{|l|r|r|r|r|r|r|r|r|r|r|r|}
\hline Exports (\% of total national exports) & 2.85 & 0.85 & 0.81 & 0.42 & 0.25 & 0.14 & 0.11 & 0.09 & 0.06 & 0.04 & 0.04 \\
\hline Imports (\% of total national imports) & 1.66 & 0.36 & 0.19 & 0.08 & 0.08 & 0.07 & 0.15 & 0.05 & 0.42 & 0.08 & 0.06 \\
\hline Exports (\% of world exports) & 3.53 & 3.91 & 8.13 & 9.25 & 4.17 & 1.41 & 2.21 & 2.81 & 0.65 & 0.96 & 1.78 \\
\hline Imports (\% of world imports) & 2.00 & 1.56 & 2.33 & 1.77 & 1.41 & 0.81 & 2.6 & 1.78 & 3.8 & 1.97 & 3.5 \\
\hline Share of top 3 export markets (\%) & 59.8 & 63.1 & 67.1 & 56.1 & 52.7 & 66.1 & 92.7 & 70.6 & 81.8 & 65.9 & 58.4 \\
\hline Share of top 3 exported products (\%) & 58.8 & 97.9 & 87.4 & 100 & 97.3 & 98.6 & 97.9 & 100 & 94.3 & 100 & 100 \\
\hline Balassa Index/RCA Index & 3.9 & 4.3 & 9.0 & 10.5 & 4.2 & 1.6 & 2.2 & 3.0 & 0.8 & 1.3 & 2.0 \\
\hline Industry- SITC 2016 & 4400 & 4407 & 4418 & 4410 & 4411 & 4412 & 4401 & $\mathbf{4 4 0 9}$ & $\mathbf{4 4 0 3}$ & $\mathbf{4 4 0 8}$ & 4415 \\
\hline Exports (US\$, millions) & 4,700 & 1,363 & 1,337 & 712 & 473 & 234 & 170 & 132 & 90 & 53 & 53 \\
\hline Balance (US\$, millions) & 1,829 & 725 & 1,044 & 533 & 273 & 121 & -50 & 45 & -642 & -57 & -54 \\
\hline RTB & 24.2 & 36.3 & 64.1 & 59.8 & 40.6 & 34.8 & -12.8 & 20.6 & -78.1 & -34.6 & -33.7 \\
\hline Exports (\% of total national exports) & 3.09 & 0.90 & 0.88 & 0.47 & 0.31 & 0.15 & 0.11 & 0.09 & 0.06 & 0.04 & 0.03 \\
\hline Imports (\% of total national imports) & 1.82 & 0.40 & 0.19 & 0.11 & 0.13 & 0.07 & 0.14 & 0.05 & 0.46 & 0.07 & 0.07 \\
\hline Exports (\% of world exports) & 3.72 & 3.92 & 8.70 & 9.51 & 5.03 & 1.55 & 2.18 & 2.89 & 0.68 & 1.89 & 1.74 \\
\hline Imports (\% of world imports) & 2.23 & 1.75 & 2.23 & 2.41 & 2.19 & 0.83 & 2.44 & 1.94 & 4.48 & 3.51 & 3.77 \\
\hline Share of top 3 export markets (\%) & 58.4 & 63.9 & 67.3 & 50.3 & 44.9 & 65.2 & 92.9 & 68.0 & 77.8 & 54.7 & 58.2 \\
\hline Share of top 3 exported products (\%) & 58.5 & 98.0 & 87.6 & 100 & 97.1 & 99.0 & 100 & 93.0 & 100 & 100 & 100 \\
\hline Balassa Index/RCA Index & 4.0 & 4.1 & 8.8 & 9.4 & 5.2 & 1.7 & 2.2 & 3.0 & 0.8 & 2.0 & 1.5 \\
\hline
\end{tabular}

Source: Authors' analysis based on ITC, 2018. Note: See table 1 for the names of the product groups (SITC)

As shown in Table 4, Austria's wood export (SITC 44) also fluctuated, slowly increased from $\$ 4.85$ billion in 2012 to $\$ 5.03$ billion in 2014, and then declined to $\$ 4.35$ billion, before rising to $\$ 4.70$ billion in 2016. UNECE (2018) argued that diseases and adverse weather effects have led to the deterioration of the overall economic indicators of forest (wood) sector.

Interestingly, both Austria and Czechia witnessed continued positive trade balance in overall wood trade (SITC 4400) for the period 2012 and 2016 (Table 3 and Table 4). Also, Czechia recorded substantial positive net relative trade balance (RTB) in all the top ten product groups. On the other hand, Austria witnessed negative trade balance and RTB in four out of ten major export product groups: SITC 4401; SITC 4403; SITC; and SITC 4408 ${ }^{1}$ between 2012 and 2016. Undoubtedly, Austria reported negative trade balance in product SITC 4403 because the country imported the raw wood to add value for domestic consumption and re-export, unlike Czechia that exported wood in its rough form, substantially.

Bojnec and Ferto (2011) argue that the CEE countries export lower valueadded raw wood and semi-finished wood products to Austria. On the other hand,

${ }^{1}$ See the product groups in details: SITC 4403 (wood in the rough); SITC 4421 (articles of wood); and SITC 4408 (veneer sheets \& sheets for plywood, etc.) 
Austria exports higher value-added wood products to the CEE countries. Similarly, studies by UNECE (2017) shows that in 2016, the increased supply of raw timber from Czech forests was substantially used to stimulate export to Germany, which grew year - on - year by $+12.2 \%$.

The findings also reveal that wood exports have been more critical in Austria's economy, both in values and share of total exports than the Czechia. Even though the global share reduced from $6.4 \%$ and $11.4 \%$ in 1995 to $3.0 \%$ and $6.9 \%$ in 2011 in Czechia and Austria respectively (FAO, 2014a), it was still substantial. It gradually reduced to an average of $2.9 \%$ (Austria) and $1.3 \%$ (Czechia) share of total national exports between 2012 and 2016 (Table 3; Table 4), indicating that other economic activities have outperformed wood export in the country.

The competitiveness based on the product structure or group is also shown in Table 3 and Table 4. As presented in Table 3, the structure of Czechia's wood exports has been dominated by wood product groups: SITC 4403; SITC 4407; SITC 4410; SITC 4418; and SITC 4415. ${ }^{2}$ Analyzing the development of Czech's wood industry, Kupčák and Šmída (2015) argue that, although the firms in the wood sector have witnessed active participation of foreign activities, which improved operations and technologies. Nevertheless, the firms' activities have been concentrated in semi-finished wood products with a high proportion of raw products at the expense of added value exported. Similarly, UNECE (2017b) stresses that Czechia's wood export has been characterised by raw timber, notably round and sawn wood. For instance, between 2014 and 2015, the round wood export accounted for 38\% and $35 \%$ of its total harvest, respectively. UNECE (2018) argues that the development has had an adverse implication for the local wood processing industry in the country. Czechia's positive trade balance in raw timber grew despite price fluctuation in 2016. Similarly, $99 \%$ of the raw timber exported by Czechia was supplied to EU-28 countries, notably, Austria, Germany and Slovakia, accounting for $49.2 \%$, $40.2 \%$ and $2.9 \%$, respectively in 2016 .

A closer look at the product groups in Czechia indicates that SITC 4403 recorded highest in dollar values. Similarly, SITC 4415 recorded highest in relative trade balance (RTB) within the period between 2012 and 2012 (Table 3). As presented in Table 4, the structure of Austria's wood exports has been dominated by wood product groups: SITC 4407; SITC 4418; SITC 4410; SITC 4411; and SITC 4412. ${ }^{3}$ The trade indicators show Austria with the most export product groups in values (SITC 4107), and product group SITC 4418 recorded highest with relative trade balance (RTB) for the period between 2012 and 2016.

${ }^{2}$ See the product groups in details: SITC 4403 (Wood in the rough); SITC 4407 (wood sawn/ chipped lengthwise, sliced/peeled); SITC 4410 (particle board and similar board of wood); SITC 4418 (builders' joinery and carpentry of wood); SITC 4415 (packaging materials of wood)

${ }^{3}$ See the product groups in details: SITC 4411 (fibreboard of wood or other ligneous materials); and SITC 4412 (plywood, veneered panels and similar laminated wood) 
Also, unlike Czechia that has witnessed positive trade balance in all the 10 product groups, Austria has recorded negative trade balance in about five product groups (SITC 4401; SITC 4403; SITC 4408; and SITC 4415) within the period between 2012 and 2016. Also, competitiveness based on the product structure shows that both countries wood export products have been diversified. Also, Austria substantially processed its wood products before exportation. It partially explains why the country has considerably recorded negative values in RTB in product group SITC 4403 (wood in rough).

As earlier explained, Balassa Index/RCA Index is used to identify comparative (dis)advantages in countries. Table 3 and Table 4, also show the Balassa Index/RCA Index in Czechia and Austria, respectively between 2012 and 2016. As shown in Table 3, the findings reveal that Czechia has had a comparative advantage in the total wood products (SITC 4400), averaging over 4 for the whole period under study. A critical look at the product groups shows that Czechia recorded the highest comparative advantages in SITC 4415, SITC 4410, and SITC 4403. The findings indicate that the country has a comparative advantage in almost all the top ten wood products), albeit weak RCA in some products. Arguably, Czechia mostly has a comparative advantage in raw wood and semi-finished wood products, but low processed products. Although studies by Sujová and Hlaváčková (2015) reveal that Czechia has had a comparative advantage in processed wood products, their results indicate that the country's RCA has a negative, decreasing trend despite increasing net exports. Thus, the sector gradually loses its competitive ability, partially attributed to the low specialization of the country in the value-added in the product groups.

As shown in Table 4, the findings reveal that Austria has had a comparative advantage in the total wood products (SITC 4400), averaging over 4 for the whole period under study. A critical look at the product groups shows that RCA index in Austria has changed over the years. The country revealed highest comparative advantage in SITC 4418 (11.9) in 2012, and recorded highest in product SITC 4410 (9.4), followed by products SITC 4418 (8.8), SITC 4411 (5.2), and SITC 4407 (4.1). Arguably, unlike Czechia that largely has a comparative advantage in raw wood and semi-finished wood products, Austria has a comparative advantage in semiprocessed and processed wood products. Similarly, studies by Dieter and Englert (2007) also revealed that Austria has a comparative advantage in both semi-processed and processed wood products.

By and large, the RCA results indicate that these countries have had a comparative advantage in the wood sector (SITC 4400), and in almost all the top ten wood product groups, albeit Austria has been more competitive global market than Czechia. It means that both nations could favorably compete in the world markets with the wood products. This may be because trade within the EU common market has been supported and the countries' seriousness in the wood industry and trade. 


\subsection{Trade Performance Index (TPI)}

TPI, as developed by the ITC, assesses and monitors the multi-faceted indicators of export competitiveness and performance by sector (wood and articles of wood in this study) in 148 ( $\mathrm{N}$ - the number of nations calculated) countries in the world. The TPI for Czechia and Austria is presented in Table 5, divided into three sections: general profile (indicators from G1 to G6); the composite index (indicators from P1 to P5); and the decomposition of changes (indicators from $\mathrm{C} 1$ to $\mathrm{Cld}$ ) in the world markets.

The performance indicators from G1 to G6 represent the general profile of the two countries' export performance in wood and articles of wood. Whereas the volume of wood exports in dollar values (G1) increased from about $\$ 4.2$ billion to $\$ 4.4$ billion in Czechia, it slightly decreased from $\$ 9.7$ billion to $\$ 9.1$ billion in Austria between 2012 and 2016. Also, five-year average export growth rate (G2) indicates that Austria experienced negative values throughout while witnessed positive growth (1\%) in 2016. It demonstrates that Czechia performed slightly above Austria within the period under study. Wood exports (G3) accounted for an average of about 2\% and about 6\% of total national exports in Czechia and Austria respectively, between 2012 and 2016. Similarly, wood imports (G4) accounted for an average of $2 \%$ and about 3\% of total national imports in Czechia and Austria respectively within the same period. It signifies that wood trade has been more critical to Austria than Czechia (Table 5).

The overall relative trade balance (RTB, G5) of both countries for the period between 2012 and 2016 was substantially positive, especially in Austria. The RTB in Czechia dramatically increased from 2\% in 2012 to 15\% in 2016 (Table 5). It implies that these countries are net wood exporters as national production outweighs consumption. Similarly, the relative unit value (RUV- G6) shows that both countries' standard of quality exports was above 1 (Table 5). It signifies that the quality of wood exports in these countries has been above the world average unit quality, albeit Austria has been better than Czechia in RUV during the period under scrutiny. Arguably, this is because Austria exports more value-added wood products than Czechia (See Table 3 and Table 4). Similarly, UNECE (2017a) argued that the problems of Czech export performance hinged in low value-added of wood products (especially raw timber) exported.

The CI based on a simple average of the five rankings of recent performance indicators (P1 to P5), showcases the position of Czechia and Austria in the wood exports in the global markets. Just as shown in RTB, the index indicates that both countries have been net exporters (P1) of wood products. Also, the P2 (per capita exports (US\$/inhabitant)) shows that Austria recorded more value of per capita 
wood exports than Czechia between 2012 and 2016. It suggests that Austria's population has produced wood for global markets more than Czechia. Nevertheless, the PI has contrasted in Austria, whereas Czechia experienced a steady improvement within the same period under study. Also, P3 (share in the world market (\% share of world exports)) for Czechia and Austria shows that these countries have been global players in the wood products, albeit with minimal global share.

Export product diversification (number of equivalent products) in wood and articles of wood (P4) shows that both countries have been well diversified, almost all the product groups (SITC 4401-4421) indicate the development of the sector in the countries under review. It thus, implies that these countries have not been vulnerable to shocks in demand for the products in the global markets. Even though the wood export diversification in these countries fluctuated, it indicates that Czechia has been more diversified than Austria. Export market diversification (number of equivalent markets) in wood products (P5) shows that both countries have not been well diversified. It means that both Czechia and Austria have been concentrated or dependent on few markets for exports (Table 3 - Table 5), and thus the vulnerability to shocks within the importing countries may have been intensified.

Also, Table 5 presents the decomposition of changes (indicators from $\mathrm{C} 1$ to $\mathrm{Cld}$ ) in market shares (last 5 years) of wood products in the world for the period between 2008 and 2016. The change in competitiveness effect signifies a quota of the relative change in global market share for Czechia and Austria. The relative adverse changes of world market share $(\mathrm{Cl})$ in wood products indicates that the countries' global market share decreased, except that Czechia witnessed positive values for the period 2012-2016. It signifies that Czechia has performed better in the global market than Austria within the period under study.

As shown in Table 5, the global competitiveness effect (Cla) also indicates that Czechia (witnessed positive changes between 2011-2015 and 2012-2016) performed more than Austria (recorded negative values throughout the same period). Even though the global competitiveness effect in both countries fluctuated, Czechia's ranking improved from 70th position (between 2008- 2012) to 45th position (between 2012- 2016), whereas Austria's improved from 81st position to 67th position within the same period under study.

The initial geographic specialization $(\mathrm{Clb})$ results show negative signs in both countries throughout the period. It suggests that Czechia and Austria have not been well positioned in dynamic destination markets during the period under study. On the other hand, the initial product specialization $(\mathrm{Clc})$ results show negative signs in Austria throughout the period, except for 2015, while Czechia witnessed positive signs throughout, except for 2015. It suggests that Czechia has been more positioned in a dynamic destination for wood products than Austria. 


\section{Table 5.}

\section{TPI IN WOOD PRODUCTS (US\$ BILLIONS, \% \& RANK) IN CZECHIA AND AUSTRIA, 2012-2016}

\begin{tabular}{|c|c|c|c|c|c|c|c|c|c|c|c|c|c|c|c|c|c|c|c|c|}
\hline \multirow[b]{3}{*}{ Code $^{4}$} & \multicolumn{4}{|c|}{2012} & \multicolumn{4}{|c|}{2013} & \multicolumn{4}{|c|}{2014} & \multicolumn{4}{|c|}{2015} & \multicolumn{4}{|c|}{2016} \\
\hline & \multicolumn{2}{|c|}{ Czechia } & \multicolumn{2}{|c|}{ Austria } & \multicolumn{2}{|c|}{ Czechia } & \multicolumn{2}{|c|}{ Austria } & \multicolumn{2}{|c|}{ Czechia } & \multicolumn{2}{|c|}{ Austria } & \multicolumn{2}{|c|}{ Czechia } & \multicolumn{2}{|c|}{ Austria } & \multicolumn{2}{|c|}{ Czechia } & \multicolumn{2}{|c|}{ Austria } \\
\hline & $\begin{array}{ll}\mathrm{V} \\
\end{array}$ & $R$ & V & $R$ & V & $R$ & V & $R$ & V & $R$ & V & $R$ & V & $R$ & V & $R$ & V & $R$ & \begin{tabular}{l|l}
$\mathrm{V}$ \\
\end{tabular} & $R$ \\
\hline $\mathrm{N}$ & 146 & $\cdot$ & 146 & & $\cdot$ & 147 & . & 147 & . & 147 &. & 147 & 147 & 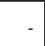 & 148 & & 148 & . & 148 & \\
\hline $\mathrm{Gl}$ & 4.20 &. & 9.75 & & 4.53 & & 10.10 & . & 4.74 &. & 10.26 & 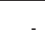 & 4.19 & $\cdot$ & 8.78 &. & 4.39 & . & 9.07 & \\
\hline G2 & 0 & 82 & $-3 \%$ & 108 & $6 \%$ & 86 & $2 \%$ & 108 & $5 \%$ & 68 & $1 \%$ & 95 & $-4 \%$ & 77 & $.5 \%$ & 86 & $1 \%$ & 52 & $-2 \%$ & 87 \\
\hline $\mathrm{G3}$ & $2 \%$ &. & $6 \%$ &. & $2 \%$ & - & $6 \%$ &. & $2 \%$ &. & $6 \%$ & 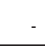 & $2 \%$ & . & $6 \%$ & 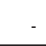 & $2 \%$ & 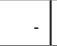 & $5 \%$ & . \\
\hline G4 & $2 \%$ &. & $3 \%$ & . & $2 \%$ & . & $3 \%$ & . & $2 \%$ &. & $3 \%$ & 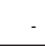 & $2 \%$ & . & $3 \%$ & . & $2 \%$ & . & $3 \%$ & \\
\hline 65 & $2 \%$ &. & $22 \%$ &. & $13 \%$ & . & $21 \%$ &. & $13 \%$ &. & $23 \%$ & . & $13 \%$ &. & $23 \%$ & . & $15 \%$ & . & $21 \%$ & \\
\hline 66 & 1.4 &. & 1.8 &. & 1.2 & . & 1.7 &. & 1.6 &. & 1.7 & 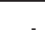 & 1.1 &. & 1.5 &. & 1.7 & . & 1.7 & . \\
\hline $\mathrm{Pl}$ & 0.90 & 17 & 3.54 & 9 & 1.10 & 18 & 3.63 & 9 & 1.12 & 18 & 3.86 & 9 & 1.01 & 16 & 3.31 & 9 & 1.16 & 17 & 3.22 & 9 \\
\hline P2 & 399 & 15 & 1,152 & 4 & 431 & 15 & 1,191 & 5 & 451 & 14 & 1,203 & 5 & 397 & 14 & 1,097 & 4 & 415 & 14 & 1,037 & 4 \\
\hline P3 & $1.3 \%$ & 22 & $2.9 \%$ & 9 & $1.3 \%$ & 21 & $2.9 \%$ & 9 & $1.3 \%$ & 21 & $2.8 \%$ & 10 & $13 \%$ & 22 & $1.6 \%$ & 12 & $1.3 \%$ & 21 & $2.8 \%$ & 17 \\
\hline P4 & 24 & 14 & 18 & 23 & 21 & 14 & 21 & 15 & 21 & 16 & 22 & 15 & 21 & 16 & 22 & 15 & 21 & 16 & 21 & 17 \\
\hline P5 & 8 & 55 & 8 & 53 & 8 & 55 & 8 & 52 & 7 & 59 & 8 & 52 & 7 & 57 & 8 & 48 & 7 & 58 & 8 & 52 \\
\hline $\mathrm{Cl}$ & $-0.4 \%$ &. & $-3.1 \%$ &. & $-0.8 \%$ & . & $-3.2 \%$ &. & $1.0 \%$ &. & $-2.0 \%$ & . & $-0.8 \%$ & . & $-1.8 \%$ & . & $1.3 \%$ & . & $-1.5 \%$ & . \\
\hline $\mathrm{Cla}$ & $-0.2 \%$ & 70 & $-0.7 \%$ & 81 & $-0.8 \%$ & 82 & $-0.01 \%$ & 74 & $0.2 \%$ & 72 & $-0.3 \%$ & 77 & $4.0 \%$ & 30 & $-0.6 \%$ & 70 & $1.7 \%$ & 45 & $-0.3 \%$ & 67 \\
\hline $\mathrm{Clb}$ & $-1.7 \%$ & 118 & $-1.8 \%$ & 121 & $1.6 \%$ & 118 & $-1.9 \%$ & & $-0.5 \%$ & 101 & $-1.2 \%$ & 123 & $-1.9 \%$ & 128 & $-2.0 \%$ & 130 & $-0.8 \%$ & 91 & $-1.0 \%$ & 106 \\
\hline $\mathrm{Clc}$ & $1.1 \%$ & 48 & $-0.2 \%$ & 75 & $1.0 \%$ & 54 & $.0 .5 \%$ & 93 & $0.6 \%$ & 76 & $.0 .3 \%$ & 93 & $-0.6 \%$ & 99 & $0.5 \%$ & 68 & $0.8 \%$ & 60 & $.0 .5 \%$ & 95 \\
\hline Cld & $0.4 \%$ & 69 & $-0.4 \%$ & 88 & $0.6 \%$ & 50 & $-0.8 \%$ & 90 & $0.7 \%$ & 46 & $0.2 \%$ & 68 & $-2.3 \%$ & 116 & $0.3 \%$ & 67 & $-0.4 \%$ & 86 & $0.4 \%$ & 63 \\
\hline$A$ & $-0.01 \%$ & 118 & $-0.1 \%$ & 140 & $0.0 \%$ & 127 & $-0.1 \%$ & 144 & $0.0 \%$ & 21 & $-0.1 \%$ & 141 & $-0.0 \%$ & 124 & $-0.1 \%$ & 140 & $0.02 \%$ & 17 & $0.0 \%$ & 140 \\
\hline
\end{tabular}

Source: Authors' analysis based on ITC, 2018. ${ }^{5}$ Note: C1a - C1d = Change 2008-2012 for Change Index 2012; C1a $-\mathrm{C} 1 \mathrm{~d}=$ Change 2011-2015 for Change Index 2015; C1a $-\mathrm{Cld}=$ Change 2012-2016 for Change Index 2016; V= values; $\mathrm{R}=$ global ranking; see table 2 for better understanding of table 5

Also, the positive and negative adaptation effects $(\mathrm{Cld})$ and the global ranking in wood products show that the ability of both countries to adjust their wood

${ }^{4}$ For better understanding of the Codes (abbreviations): N= Number of exporting countries for the ranking in the sector; G1= Value of exports (in billions US\$); G2= Export growth in value (\%); G3= Share in national exports (\%); G4= Share in national imports (\%); G5= Relative trade balance (\%); G6 Relative unit value (world average $=1$ ); P1= Net exports (in billions US\$) P2 Per capita exports (thousand US\$/inhabitant); P3= Share in the world market (\%); P4= Product diversification (Number of equivalent products); P5= Market diversification (Number of equivalent markets); $\mathrm{C} 1=$ Relative change in world market share (\%); $\mathrm{C} 1 \mathrm{a}=$ Competitiveness effect $(\%) ; \mathrm{C} 1 \mathrm{~b}=$ Initial geographic specialisation (\%); $\mathrm{C} 1 \mathrm{c}=$ Initial product specialisation (\%); $\mathrm{C} 1 \mathrm{~d}=$ Adaptation effect $(\%) ; \mathrm{A}=$ Absolute change of world market share (\% points)

5 The calculation includes wood, wood products and paper (SITC Rev. 3) as follows: 244 cork, natural, raw; waste; 633 cork manufactures; 245 fuel wood, wood charcoal; 634 veneers, plywood, etc.; 246 wood in chips, particles; 635 wood manufactures, nes; 247 wood rough, rough squared; 641 paper and paperboard; 248 wood, simply worked; 642 paper, paper board, cut, etc; 251 pulp and waste paper; 8215 wooden furniture 
exports (supply) to changes in the worldwide demand has fluctuated over time. It also suggests that these countries' market shares in importing partners have not been dramatically improved as expected.

\subsection{Trading Partners, Vulnerability and Market Access}

Given that Czechia and Austria accounted for about $2 \%$ and 4\%, respectively, of global exports of wood products (SITC 44) in dollar values in 2016 (ITC, 2018), there is a need to know the top importing partners from these countries. Historically, Czechia has substantially exported more wood products to Austria (accounting about 25\% of Czechia's wood exports in 2016) than Austria to Czechia (accounting about 3\% of Austria's wood exports in 2016). Table 6 presents the top export destinations for Czechia and Austria's wood products (SITC 44) in 2016. Germany, Austria, Slovakia, Italy and Poland, have been the leading wood importing countries from Czechia. Similarly, Germany, Italy, Switzerland, Japan, and France have been the leading importers of wood products from Austria.

A critical look at the export destinations shows that Czechia (heavily concentrated as top 5 countries, accounted for over $81 \%$ ) has been highly volatile more than Austria (top 5 countries accounted for over 67\%) in 2016. Interestingly, Germany is the top destination for both countries (Table 6). Studies by UNECE (2018) indicate that Czechia's export into EU-28 accounted for about $99 \%$ out of the total export thereof $52 \%$ into Austria, about 39\% into Germany, 5\% into Italy and about $4 \%$ into Slovakia in 2017. Similarly, raw timber was imported mainly from EU-28 countries (89.7\%) as follows: 34.6\%, 31.7\% and 13.3\% from Slovakia, Poland and Germany respectively.

Also, the total wood trade in these countries has mainly been within the EU common market. Arguably, the EU's single market policy, coupled with the ease of doing business (EDB) in the partner markets may have encouraged Czechia and Austria to concentrate in these few countries for wood exports (see Table 3 and Table 4 for a share of top export markets; Table 6). Nevertheless, the vulnerability of these countries to shocks within their destination partners has been intensified.

The findings also pointed out that intra-industry specialization has increased with the level of value added to products. Even though these countries' average export growth rates between the period 2012-2016 declined (by -1\% Czechia and $-2 \%$ Austria), it rose (by 5\% Czechia and 8\% Austria) between 2015 and 2016. The growth potential of demand for wood products and its market size might have been the factors that drive the product attractiveness within the areas. Nevertheless, there is a need for market diversification beyond the European borders to reduce global market shocks, stimulate competitiveness, and earnings to be sustained 
Table 6.

CZECHIA AND AUSTRIA'S LARGEST WOOD EXPORT MARKETS (SITC 44, US\$ MILLIONS, \%, INDEX) IN 2016

\begin{tabular}{|c|c|c|c|c|c|c|c|c|c|}
\hline Indicator & $\begin{array}{c}\text { Ex } 2016 \\
\text { (US\$) }\end{array}$ & $\begin{array}{c}\text { Bal. } \\
2016 \\
\text { (US\$) }\end{array}$ & $\begin{array}{c}\text { ExShare } \\
(\%)\end{array}$ & \begin{tabular}{|c|} 
ExG \\
$2012-$ \\
$16(\%)$ \\
\end{tabular} & $\begin{array}{c}\text { ExG } \\
2015- \\
16(\%)\end{array}$ & Rank & RTB & Tariff & EDB \\
\hline \multicolumn{10}{|c|}{ Czechia- exports } \\
\hline Total export & $1,994.6$ & $1,041.8$ & 100 & -1 & 5 & - & 35.4 & - & - \\
\hline Germany & 818.7 & 604.5 & 41 & 2 & 5 & 4 & 58.5 & 0 & 17 \\
\hline Austria & 495.3 & 368.8 & 24.8 & -1 & 13 & 11 & 59.5 & 0 & 19 \\
\hline Slovakia & 132.7 & -7.0 & 6.7 & -5 & 16 & 43 & -2.6 & 0 & 33 \\
\hline Italy & 100.8 & 89.2 & 5.1 & -3 & -4 & 6 & 79.2 & 0 & 50 \\
\hline Poland & 65.2 & -121.8 & 3.3 & - & - & 21 & -48.3 & 0 & 24 \\
\hline EU 28 & $1,855.2$ & $1,046.3$ & 93.0 & - & - & - & - & - & - \\
\hline \multicolumn{10}{|c|}{ Austria- exports } \\
\hline Total export & $4,700.2$ & $1,828.8$ & 100 & -2 & 8 & - & 24.2 & - & - \\
\hline Germany & $1,217.0$ & 99.8 & 25.9 & -1 & 9 & 4 & 4.3 & 0 & 17 \\
\hline Italy & $1,165.4$ & $1,060.4$ & 24.8 & -5 & 2 & 6 & 83.5 & 0 & 50 \\
\hline Switzerland & 361.6 & 304.6 & 7.7 & -3 & 3 & 14 & 72.7 & 0 & 31 \\
\hline Japan & 222.3 & 221.3 & 4.7 & -11 & 11 & 3 & 99.2 & 2.6 & 34 \\
\hline France & 191.6 & 177.8 & 4.1 & -4 & 11 & 7 & 86.6 & 0 & 29 \\
\hline EU 28 & $3,487.10$ & 847.8 & 74.2 & - & & - & & - & \\
\hline
\end{tabular}

Source: Authors' analysis based on ITC, 2018. Note: Ex 2016 = Value exported in 2016 (US\$ millions); Bal. $=$ Trade balance 2016 (US $\$$ millions); ExShare $=$ Share in a country's exports $(\%)$; ExG $=$ growth in exported value between 2012-2016 (\%); Tariff = Average tariff (most favoured nations-MFN) faced by Czechia and Austria (\%); EDB= Ease of doing business ranking in the importing country in 2016

Although there is market access for trade in wood products within the EU borders, non-EU countries charge import duties. For instance, Czechia and Austria have free market access (zero tariffs) to export wood products within the EU single market (Table 6).

However, these countries faced some tariffs in countries outside the EU common market. For instance, importing countries charged an average import duty for wood products (SITC 44) from Czechia and Austria up to 2.6\% in Japan, 4.3\% (Australia), 8.8\% (Russia), 9.1\% (Pakistan), 10.3\% (Argentina), 10.8\% (Malaysia), an 18.9\% (Kenya), in 2016 (ITC, 2018). Arguably, tariffs faced by Czechia and Austrian exporters in other continents might have partly partially impeded these economies, from penetrating the non-EU markets and contributed to export concentration within the EU single market. 


\section{CONCLUSIONS}

Globally, wood production and trade have been identified as an essential sector for economic performance in countries that have developed the industry, thus the relevance of this study. Therefore, some methods, such as Balassa RCA, relative trade balance (RTB), and diversification ratios were used to assess the export performance and competitiveness of Czechia and Austria in wood products in recent years.

The RCA results show that both countries have been competitive in the global market for total wood products just as the states have witnessed positive in RTB within the period under study. Diversification ratios reveal that both countries concentrated in few markets (mainly within the EU single market) for exports of wood products. Arguably, the countries appear to have been vulnerable to external market shocks as they have relied on few markets for exports.

Similarly, the export competitiveness based on the product groups shows that both countries, notably Austria's wood products have been diversified and mostly processed before exports. In summary, both countries have performed impressively within the period under study even though the time series for the research was short. Nevertheless, there is a need for market export diversification beyond the EU's single market. For instance, product structure shows the most export products in dollar values (SITC 4403), RCA (SITC 4415), and RTB (SITC 4415) in Czechia. In Austria, the product structure shows the most export products in dollar values (SITC 4107), RCA (SITC 4110), and RTB (SITC 4418). By and large, Austria and Czechia have performed and remained competitive in the global wood markets. Nevertheless, there is a need for export diversification in both countries beyond the EU single market. Wood processing industries should be stimulated to increase in semi-processed and high wood processed products in some of the product groups that these countries seemingly have factor endowments. Specifically, Czechia should improve and sustain its value-added in most of the wood product groups for domestic consumption and exports relative to Austria.

\section{References}

Arnold, M. (2002). Clarifying the links between forests and poverty reduction. The International Forestry Review, 4(3), 231-233. Available at: https://www.jstor. org/stable/43739411

Balassa, B. (1965). Trade liberalization and "revealed" comparative advantage. The Manchester School, 33(2), 99-123. Available at: https://doi. org/10.1111/j.1467-9957.1965.tb00050.x 
Balassa, B. (1979). The changing pattern of comparative advantage in manufactured goods. Review of Economics and Statistics, 61(2), 259-266. https:// www.jstor.org/stable/1924594

Bojnec, Š. \& Ferto, I. (2011). Trade in raw and semi-finished wood products of Hungary and Slovenia with Austria. Journal of Forest Science, 128 (3), 157176.

Bojnec, Š. \& Fertő, I. (2014). Forestry industry trade by degree of wood processing in the enlarged European Union countries. Forest Policy and Economics, 40, 31-39. Available at: https://doi.org/10.1016/j.forpol.2013.11.009

de Carvalho, K. H. A., da Silva, M. L., \& Soares, N. S. (2009). Competitiveness of Brazilian wood pulp in the international market. Cerne, 15(4), 383-390.

Dieter, M., Englert, H. (2007). Competitiveness in the global forest industry sector: an empirical study with special emphasis on Germany. European Journal of Forest Research, 126 (3), 401-412. http://dx.doi.org/10.1007/s10342-0060159-x 5 .

FAO. (2014a). Contribution of the forestry sector to national economies, 1990-2011, by A. Lebedys and Y. Li. Forest Finance Working Paper FSFM/ACC/09. Rome: FAO

FAO. (2014b). State of the world's forests 2014: enhancing the socioeconomic benefits from forests. Rome: FAO.

FAO. (2016). State of the world's forests 2016: forests and agriculture: land-use challenges and opportunities. Rome: FAO.

Gonuguntla, S. (2007). New Zealand forestry - an analysis of comparative advantage. New Zealand Journal of Forestry, 51 (4), 21-27.

Granabetter, D. (2016). Revealed comparative advantage index: an analysis of export trade in the Austrian district of Burgenland. Review of Innovation and Competitiveness: A Journal of Economic and Social Research, 2(2), 97-114. Available at: https://hrcak.srce.hr/162334

Han, X., Wen, Y. \& Kant, S. (2009). The global competitiveness of the Chinese wooden furniture industry. Forest Policy and Economics, 11(8), 561-569. Available at: https://doi.org/10.1016/j.forpol.2009.07.006

ITC. (2018). Statistical database [Online]. Available at: http://bit.ly/1EowRPT. [Accessed 2018, April 15].

Kupčák, V. \& Šmída, Z. (2015). Forestry and wood sector and profitability development in the wood-processing industry of the Czech Republic. Journal of Forest Sciences, 61 (6), 244-249. Available at: https://doi.org/10.17221/113/2014-JFS

Krugman, P. (1994). Competitiveness: a dangerous obsession. Foreign Affairs, 73(2), 28-44. Available at: https://www.jstor.org/stable/20045917 
Liesner, H. H. (1958). The European common market and British industry. The Economic Journal, 68(270), 302-316. Available at: https://www.jstor.org/stable/2227597

Nambiar, A.O. E. S. (2015). Forestry for rural development, poverty reduction and climate change mitigation: we can help more with wood. Australian Forestry, 78(2), 55-64. Available at: https://doi.org/10.1080/00049158.2015.1050776

Noor, A. Z., Roda, J. M., \& Ahmad, F. P. (2008). Research report on the evaluation on malaysian wood products to Europe-a comparative advantage perspective in regards of recent evaluations in European forest sector. Kepong: Forest Research Institute Malaysia. [Accessed 2018-12-07]. Available from: https:// bit.ly/2SGezbP.

Paluš, H., Parobek, J. \& Liker, B. (2015). Trade performance and competitiveness of the Slovak wood processing industry within the Visegrad group countries. Wood Industry/Drvna Industrija, 66(3), 195-203. Available at: https://hrcak. srce.hr/145340

Porter, M. (1990). The competitive advantage of nations. New York: Free Press.

Priede, J. \& Pereira, E. T. (2015). European Union's competitiveness and export performance in context of EU-Russia political and economic sanctions. Procedia-Social and Behavioral Sciences, 207, 680-689. Available at: https:// doi.org/10.1016/j.sbspro.2015.10.138

Sujová, A. \& Hlaváčková, P. (2015). Sectoral analysis of competitiveness of wood processing industry in the Czech Republic. Acta Universitatis Agriculturae et Silviculturae Mendelianae Brunensis, 63(1), 293-302. https://acta.mendelu. cz/63/1/0293/

Sujová, A., Michal, J., Kupčák, V. \& Dudík, R. (2017). The impact of international trade of raw wood to the economic growth of forest-based sectors in the Czech and Slovak Republics. BioRes., 12(1), 1102-1111.

United Nations Economic Commission for Europe (UNECE) (2017a). Austrian market report 2017. UNECE. Available at: https://bit.ly/2yx0XKz [Accessed 2018, May 15].

UNECE (2017b). Market statement of the Czech Republic 2016. UNECE. Retrieved from: https://bit.ly/2tuT8iS [Accessed 2018, May 15].

UNECE (2018). Market statement of the Czech Republic 2017. UNECE. Retrieved from: https://bit.ly/2reqstR [Accessed 2018, November 29].

UNECE/FAO. (2017). Forest products annual market review 2016-2017. Geneva: United Nations.

UNECE/FAO. (2018). Green jobs in the forest sector. Timber and Forest Discussion Papers. Geneva: United Nations. 
World Bank. (2018). World development indicators: rural environment and land use. Washington, DC.: World Bank

World Economic Forum (WEF). (2018). The global risks report 2018. Geneva: WEF.

Zdráhal, I. \& Bečvárová, V. (2018). Entry into the common market of the European Union in terms of Czech Republic's foreign trade with dairy products. Acta Universitatis Agriculturae et Silviculturae Mendelianae Brunensis, 66(2), 605-616. Available at: https://acta.mendelu.cz/66/2/0605/

\section{UČINKOVITOST IZVOZA I KONKURENTNOST DRVNIH PROIZVODA U ČEŠKOJ I AUSTRIJI}

Summary

Ovaj članak analizira kretanje izvoza drva u Češkoj i Austriji posljednjih godina. Neki se pristupi, poput otkrivene komparativne prednosti (RCA), indeksa relativne trgovinske bilance (RTB) i omjera diversifikacije koriste za procjenu pokazatelja uspješnosti izvoza i konkurentnosti u tim zemljama. Rezultat RCA pristupa otkriva da su i Češka i Austrija bile konkurentne na svjetskom tržištu drva, baš kao što su i zemlje ostvarivale pozitivne RTB rezultate u promatranom razdoblju. Rezultati diversifikacije tržišta pokazuju da su se obje zemlje koncentrirale na nekoliko tržišta (uglavnom unutar jedinstvenog tržišta EU-a) za izvoz drvnih proizvoda. Također, konkurentnost na temelju strukture proizvoda pokazuje da su proizvodi u obje zemlje, posebno grupe proizvoda od drva u Austriji, raznoliki i uglavnom se obrađuju prije izvoza. Ukratko, obje su zemlje postigle nevjerojatne rezultate tijekom perioda proučavanja iako je vremenski niz za istraživanje bio kratak. Ipak, postoji potreba za diversifikacijom izvoza na tržištu izvan jedinstvenog tržišta EU.

Ključne riječi: izvoz, konkurentnost, diverzifikacija, tržište, RCA, RTB 